\title{
CANNIBALISM AS THE MAIN FEEDING BEHAVIOUR OF TUCUNARES INTRODUCED IN SOUTHEAST BRAZIL
}

\author{
GOMIERO, L. M. and BRAGA, F. M. S. \\ Departamento de Zoologia, Instituto de Biociências, Universidade Estadual Paulista, UNESP, \\ Av. 24-A, n. 1515, C.P. 199, CEP 13506-900, Rio Claro, São Paulo, Brazil \\ Correspondence to: Leandro Muller Gomiero, Departamento de Zoologia, Instituto de Biociências, \\ Universidade Estadual Paulista, UNESP, Av. 24-A, n. 1515, C.P. 199, CEP 13506-900, \\ Rio Claro, São Paulo, Brazil, e-mail: leanmg@rc.unesp.br \\ Received February 21, 2003 - Accepted July 3, 2003 - Distributed August 31, 2004
}

(With 7 figures)

\begin{abstract}
Individuals of its own genus were the main food item of two species of tucunares (Cichla cf. ocellaris and Cichla monoculus) introduced into the Volta Grande Reservoir. The abundance of adult tucunares may cause intra-specific competition, possibly leading to the high cannibalism rates found.
\end{abstract}

Key words: feeding, tucunare, Cichla, cannibalism, introduction.

\section{RESUMO}

\section{Canibalismo como principal comportamento alimentar de tucunarés introduzidos no Sudeste do Brasil}

O principal item alimentar de duas espécies de tucunarés (Cichla cf. ocellaris e Cichla monoculus) introduzidas no reservatório de Volta Grande foram indivíduos do mesmo gênero. A abundância de tucunarés adultos pode causar competição intra-específica e possivelmente justificar as altas taxas de canibalismo encontradas.

Palavras-chave: alimentação, tucunaré, Cichla, canibalismo, introdução.

\section{INTRODUCTION}

The Volta Grande Reservoir, on the Rio Grande River, is located in São Paulo and Minas Gerais states $\left(48^{\circ} 25^{\prime}\right.$ and $47^{\circ} 35^{\prime} \mathrm{W}, 1^{\circ} 57^{\prime}$ and $\left.20^{\circ} 10^{\prime} \mathrm{S}\right)$. Approximately 25 years ago the dam was closed. The reservoir, with an area of $221.7 \mathrm{~km}^{2}$ and a water volume of $2,268 \mathrm{~km}^{3}$, is used to produce electric energy. The climate is typically tropical with a mean annual temperature of $22^{\circ} \mathrm{C}$ and mean annual rainfall of $1,635 \mathrm{~mm}$. The two seasonal periods are: warm and rainy from October to April, and cool and dry from May to September (Braga \& Gomiero, 1997). The reservoir has a large abundance of tucunares, Cichla spp. Bloch \& Schneider, 1801, a fish from the Amazon basin with marked caudal ocellus.

The presence of exotic fishes species presents a serious problem because resources previously available for native fishes are scarce. This leads to competition and predation, mainly among the piscivorous species, and even causes local species extinction (Alves \& Vono, 1997). The Cichla species need clear water since they are visually oriented diurnal predators (Winemiller, 2001).

Cannibalism can be controlled poligenetically as it is a complex behavior phenomenon, acting frequently as a control mechanism in fish populations (Chevalier, 1973; Thibault, 1974). It occurs as a response to local condition influencing particular populations, and its frequency and intensity may vary substantially inside and among species (Fox, 1975). Cannibalism intensity is inverse to availability of alternative preys (Polis, 1981), and cannibal fishes consume a high-quality diet, which chemically is very similar to their own constitution (Wootton, 1990).

Fishes providing parental care may feed upon part of their brood. This occurs due to weight loss 
in periods presenting little foraging opportunity (Halliday, 1988).

The objective of this work was to measure the intensity of cannibalism in two introduced species of tucunaré, Cichla cf. ocellaris Bloch \& Schneider, 1801 and Cichla monoculus Spix \& Agassiz, 1831, in Volta Grande Reservoir, on the Rio Grande River.

\section{MATERIAL AND METHODS}

We sampled the fish in April and June of 1997 and monthly from September 1997 to August 1998, using two types of gear: gill nets and angles. Each sampling period lasted five days.

The gill nets had mesh sizes of 2.0, 3.0, 4.0, 5.0 , and $6.0 \mathrm{~cm}$ (between adjacent knots). Each net was $150 \mathrm{~m}$ long and $1.5 \mathrm{~m}$ high, totaling 750 meters for all nets. Natural or artificial baits were used in angling, resulting in the capture of a greater number of specimens.

The caudal ocelli were measured along their greater axis. This length was correlated with total fish length, using the alometric equation $y=a x^{b}$ (Vanzolini, 1993).

Stomach content was identified and preserved in $70 \%$ alcohol. When possible we also determined the number, weight, and length of every food item. The preys were analyzed with the following indexes (Matallanas, 1980, 1982a, b, c):

- numeric index $(\mathrm{Ni})$ : proportion of number of preys of one taxonomic group as a percentage of the total number of preys;

- frequency index (Fi): proportion of the number of stomachs with preys of a determined taxonomic group as a percentage of total number of stomachs with food;

- frequency in weight (Wi): proportion of preys' weight by taxonomic group as a percentage of the total weight of preys.

The feeding coefficient $(\mathrm{Q})$ was calculated with $\mathrm{Ni}$ and $\mathrm{Wi}$ by the formula: $\mathrm{Q}=\mathrm{Ni} \cdot \mathrm{Wi}$. This coefficient is classified in three categories: $\mathrm{Q}$ more than 200 (preferential prey), Q between 20 and 200 (secondary prey), and Q less than 20 (occasional prey) (Braga \& Braga, 1987).

When the $Q$ values of the preys were classified as preferential or secondary, the relative importance index was used:

$$
\mathrm{RII}=\mathrm{Fi} .(\mathrm{Ni}+\mathrm{Wi})
$$

This index indicates the real importance of each taxonomic group in the feeding habit of the fish in question (Hyslop, 1980).

The variation of feeding related to length was analyzed by length class, and for each class the average weight of the most important preys was calculated (AW).

\section{RESULTS}

In the period from April 1997 to August 1998, using gill nets and fishhooks we caught 459 C. cf. ocellaris and 170 C. monoculus.

The relation between ocellus length and total fish length was negative allometric in $C$. cf. ocellaris and isometric in C. monoculus (Table 1 and Fig. 1).

We examined 76 stomachs of $C$. cf. ocellaris and 18 of $C$. monoculus. The main food of these two species was fish, including: Cichla sp., Plagioscion squamosissimus (Heckel, 1840), and Tilapia rendalli (Boulenger, 1897) for $C$. cf. ocellaris and Cichla sp. for $C$. monoculus. The relative importance index (RII) of the items Cichla sp., P. squamosissimus, and T. rendalli indicated that Cichla sp. was the main prey of both species (Figs. 2 and 3).

In cases where the food item Cichla was found well preserved, it could be identified by scale counting, and caudal ocelli size. Cannibalism was evident in these cases.

After also separating items representing the species $P$. squamosissimus and T. rendalli, occurrence frequency revealed the dominance of the food item Cichla sp. in both species and for all length classes (Figs. 4 and 5).

In C. cf. ocellaris the item P. squamosissimus was important in the size class from 42 to $50 \mathrm{~cm}$ (Fig. 6). There were no differences among food items and size class for $C$. cf. ocellaris, according to the twoway ANOVA with single observation, applied for the data. In C. monoculus the item $T$. rendalli was important in the size class from 34 to $42 \mathrm{~cm}$ (Fig. 7).

\section{DISCUSSION}

The ocelli of both fishes grew differently, being allometric negative to $C$. cf. ocellaris and isometric to $C$. monoculus. The allometric negative growth of ocelli in $C$. cf. ocellaris was relatively 
less than the total length of the fish, however the isometric growth of ocelli of $C$. monoculus was relatively proportional to fish length. The adaptive meaning of the ocellus to Cichla monoculus must be stronger than that of Cichla cf. ocellaris. Zaret (1977) and Winemiller (1990) hypothesized that the ocellus could help in peer recognition during pair formation or as a defense against predation: the ocellus in the tail makes the head hard to distinguish

According to these authors, Zaret's first hypothesis would not be valid, because with fish size increase the ocellus tends to lose its shape and even to disappear, although reproductive activity continues normally. The second hypothesis appears to lack validity because fishes with this adaptation generally have a strip obscuring their real eyes (Barlow, 1972), which does not occur in tucunare. A third hypothesis, presented by Zaret (1977), is that coloration and the ocellus developed in the tail by juvenile tucunares (Cichla ocellaris) just after the end of parental care, is an important sign for intraspecific recognition and prevents cannibalism.

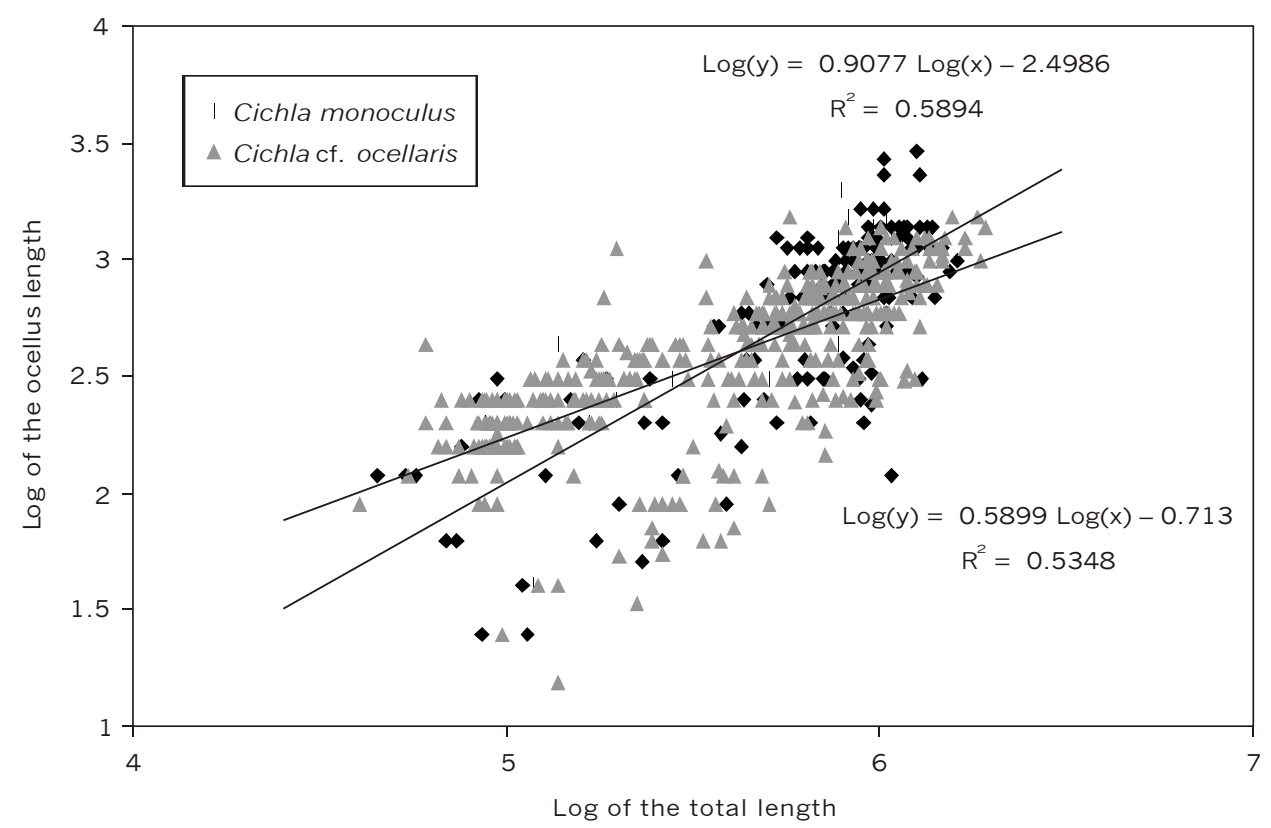

Fig. 1 - Linear regression referring to the ocellus length compared to the total length of the Cichla cf. ocellaris and Cichla monoculus.

TABLE 1

Parameters of linear regressions of the ocellus length on the total length of two Cichla species.

\begin{tabular}{|c|c|c|c|c|c|c|c|c|c|}
\hline Species/parameters & $\mathbf{A}$ & $\mathbf{B}$ & $\mathbf{a}$ & $\mathbf{S}_{\mathbf{b}}$ & $\mathbf{p}_{\mathbf{0 . 0 5}}$ & $\mathbf{R}$ & $\mathbf{N}$ & $\mathbf{s}_{\mathbf{y x}}^{\mathbf{2}}$ & \multirow{2}{*}{$\mathbf{F}_{\mathbf{0 . 0 5}}$} \\
\hline Cichla cf. ocellaris & -0.71 & 0.589 & 0.49 & 0.0224 & $\mathrm{p}<0.05$ & 0.74 & 433 & 0.050 & \multirow{2}{*}{ (F $<0.05)$} \\
\hline Cichla monoculus & -2.49 & 0.907 & 0.082 & 0.0671 & $\mathrm{p}>0.05$ & 0.76 & 169 & 0.093 & \\
\hline
\end{tabular}

$\mathrm{A}=\log$. value of the intercept; $\mathrm{B}=$ angular coefficient value; $\mathrm{a}=$ transformed value of the intercept; $\mathrm{S}_{\mathrm{b}}=\mathrm{b}$ deflection; $\mathrm{p}_{0.05}=$ probability of $\mathrm{b}$ being larger or smaller than $1 ; \mathrm{R}=$ correlation coefficient; $\mathrm{N}=$ number of data pairs; $\mathrm{s}_{\mathrm{yx}}^{2}=$ regression variance; $\mathrm{F}_{0.05}=$ result of variance homogeneity test. 


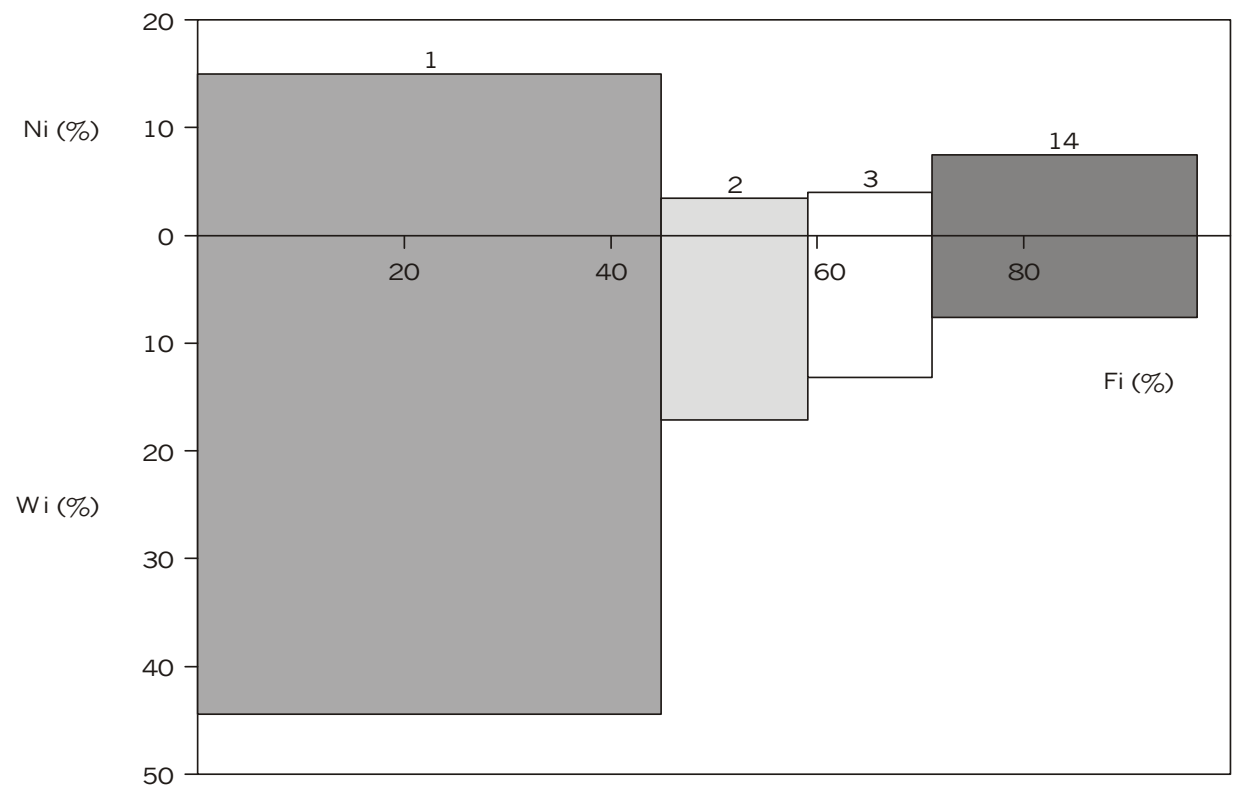

Fig. 2 - Relative importance index (RII) of the items Cichla sp. (1), Plagioscion squamosissimus (2), Tilapia rendalli (3), and fish remains (14) to Cichla cf. ocellaris.

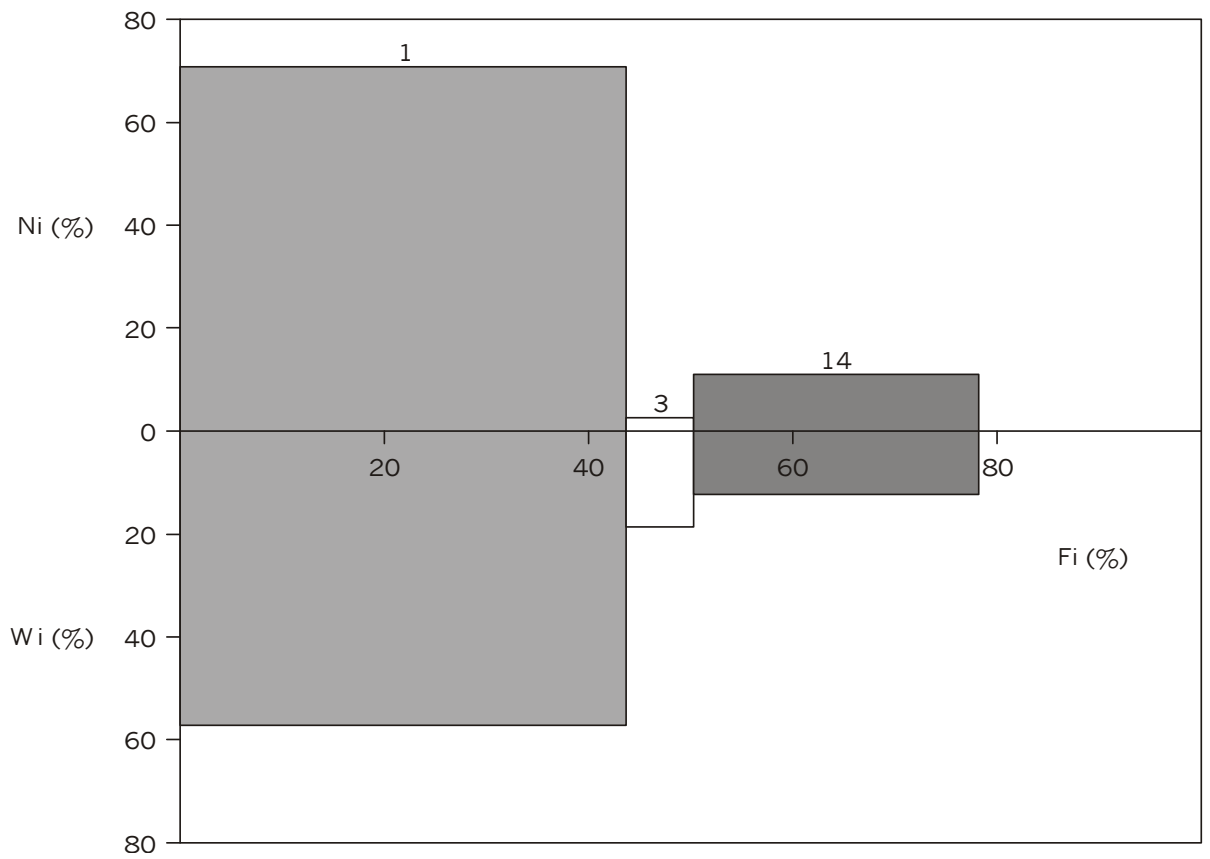

Fig. 3 - Relative importance index (RII) of the items Cichla sp. (1), Tilapia rendalli (3), and fish remains (14) to Cichla monoculus.

Two other hypotheses were also proposed. Arcifa \& Meschiatti (1993) found in tucunare stomachs only specimens that did not yet present caudal ocelli, and Lowe-McConnell (1969) suggested that the ocellus in Cichla would serve for brood orientation during parental care. 
Zaret (1977), in analyzing 300 stomachs of Cichla ocellaris from Gatun Lake, found no evidence of cannibalism. This author suggested that the following conditions prevent cannibalism: 1) the territoriality of a given couple, 2) juveniles of the same area are offspring of a single couple, and 3 ) abundance of prey. In addition to this, when juveniles become independent, shelter is found in the aquatic vegetation. Young stay in these shelters until reaching 18 to 20 centimeters, when predation pressure is lower. The caudal ocelli serve as interand intraspecific signs inhibiting predation and thus would serve as another factor reducing cannibalism. As reported, in environments lacking submerged vegetation, cannibalism occurs (Arcifa \& Meschiatti, 1993; Fox, 1975; Santos et al., 2001).

Our data indicated that Cichla sp. was the most important item in the diet of both species considered. In the sampling site, a high index of predation was found upon the genus itself (Cichla), particularly following reproduction peaks. This result disagrees with the ocellus function proposed by Zaret (1977). Better explanations for this cannibalism are: 1) the great number of adult specimens that are not predated, 2) low abundance of prey coupled with a great number of young specimens of the same genus, and
3) lack of aquatic vegetation to shelter the juveniles. Cannibalism reduces the number of intraspecific competitors. In populations where cannibalism is frequent, greater stability exists and extinction probabilities are low. However, there is a cost. If fishes prey upon their own brood, by eliminating potential partners they reduces their own reproductive chances (Chevalier, 1973; Fitzgerald, 1992; Fox, 1975; Polis, 1981).

In environments where tucunares have been introduced, high cannibalism rates can occur (Durães et al., 2000; Santos et al., 1994). They also occur, but at lower rates, in natural habitats of this genus (Jepsen et al., 1997; Winemiller, 2001).

Bedarf et al. (2001) compared two lakes; into the first one was recently introduced a predatory cichlid whereas, in the second, this species was native. In the first lake, population growth was exponential and there was little cannibalism due to prey abundance. In the second, the species found few preys and practiced large-scale cannibalism. According to the authors, in the first lake as the preys became rare and intra- and interspecific competition increased, a tendency to cannibalism developed.

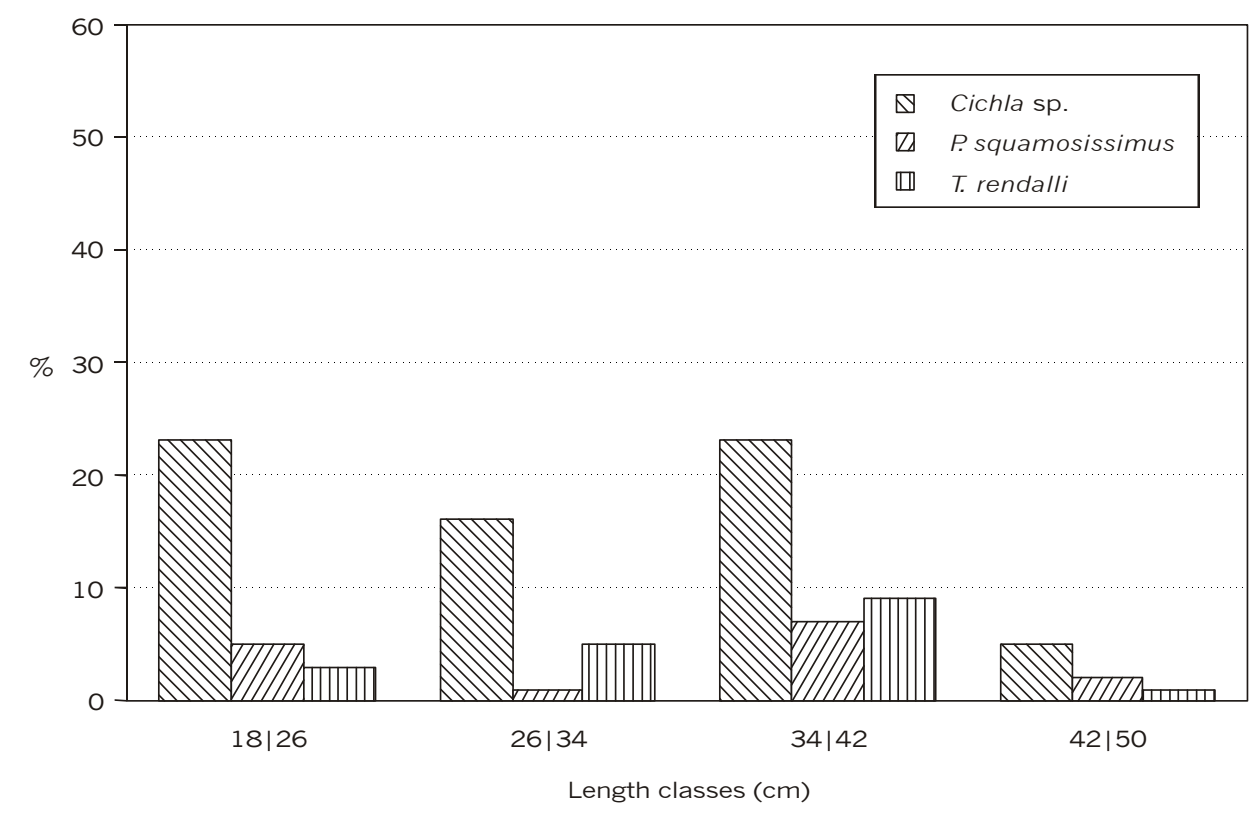

Fig. 4 - Frequency of occurrence of the three main food items per length class of Cichla cf. ocellaris. 


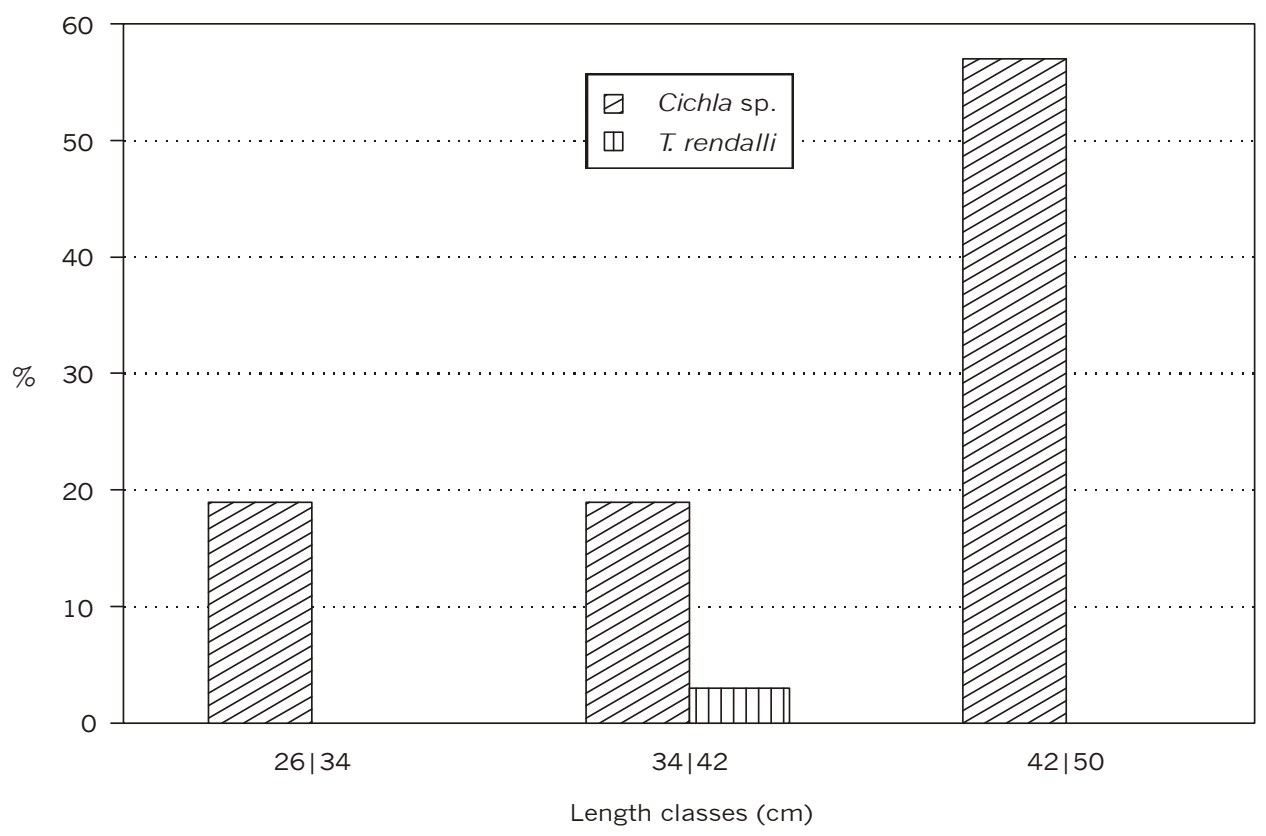

Fig. 5 - Frequency of occurrence of the two main food items per length class of Cichla monoculus.

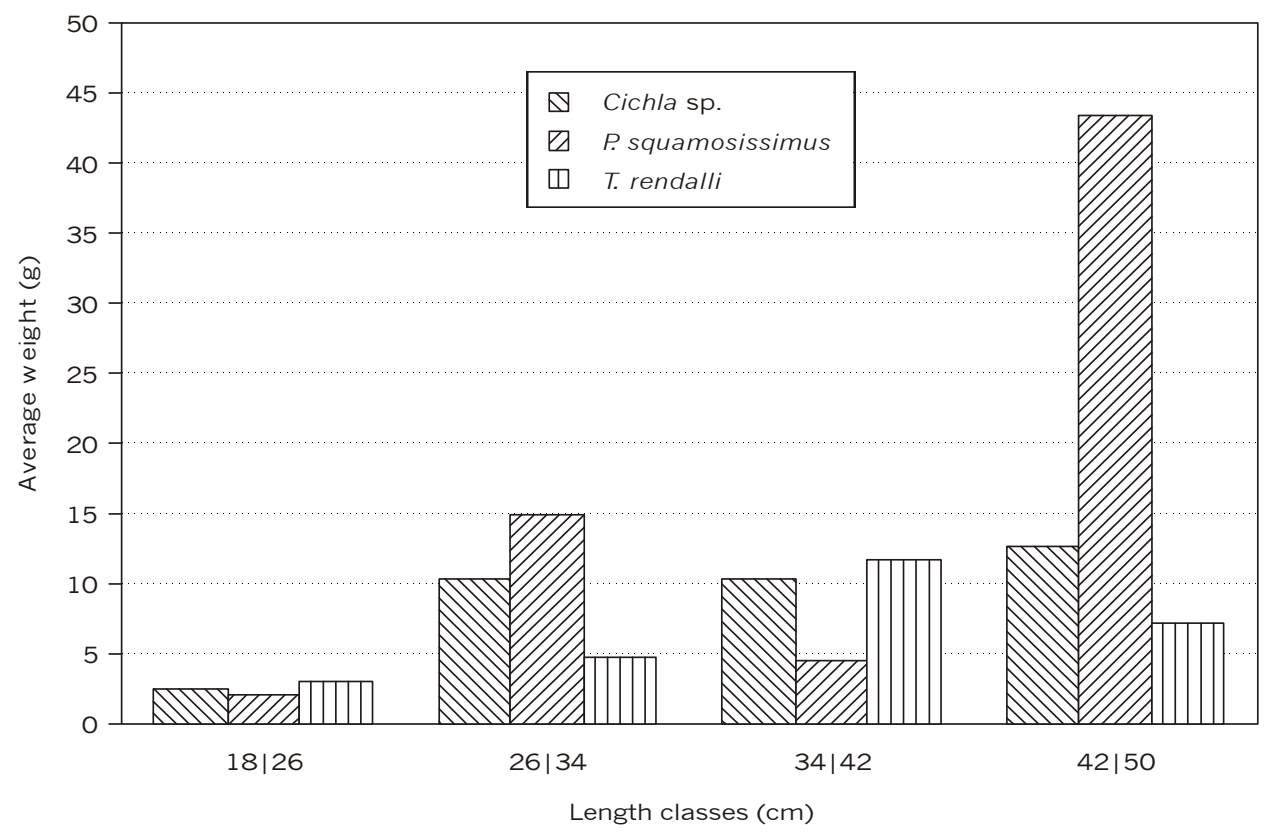

Fig. 6 - Average weight of the three main preys per length class of Cichla cf. ocellaris. 


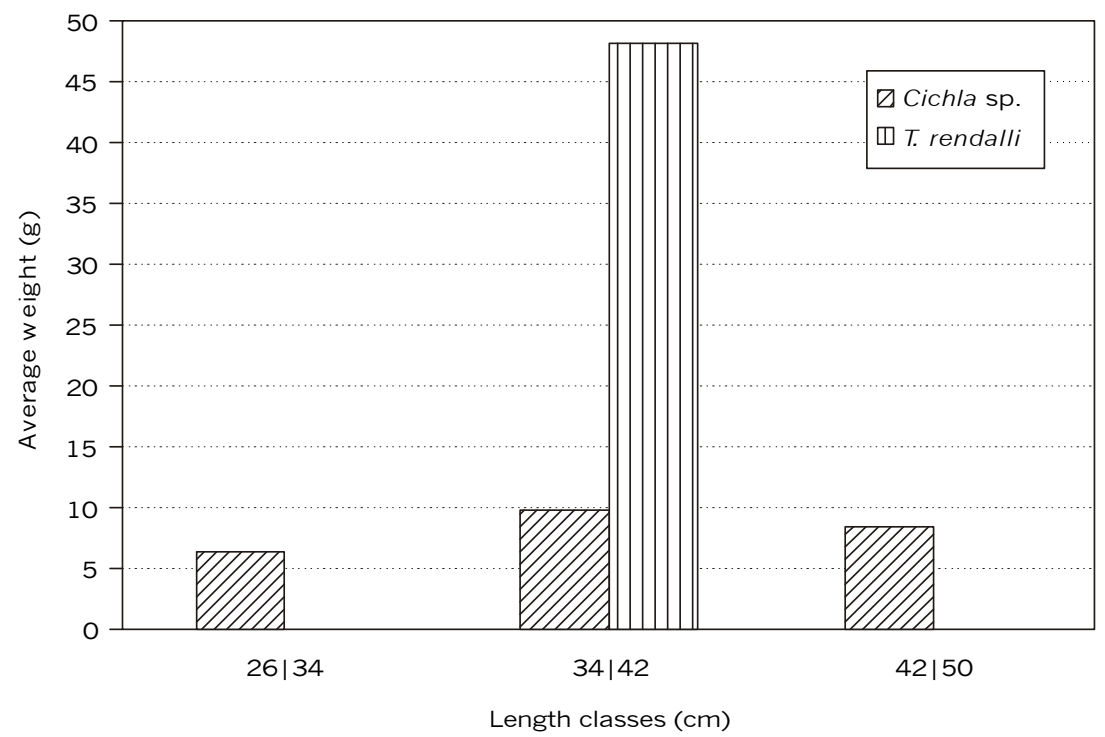

Fig. 7 - Average weight of the two main preys per length class of Cichla monoculus.

In Guri Reservoir (Venezuela), into which the tucunare had previous been introduced, cannibalism was evident in samples from 1985 to 1989 , when fishes of this genus were very abundant (Gil et al., 1996; Lasso et al., 1990; Novoa, 1996; Novoa et al., 1990). However, fish caught from 1993 to 1994 did not present cannibalism, probably because of reduced tucunare abundance (Williams et al., 1998).

Acknowledgements - We thank CAPES for financial support during studies leading to the master's degree. We are also grateful to CEMIG.

\section{REFERENCES}

ALVES, C. B. M. \& VONO, V., 1997, O caminho da sobrevivência para os peixes do rio Paraopeba. Ciência Hoje, 21(126): 14-16.

ARCIFA, M. S. \& MESCHIATTI, A. J., 1993, Distribution and feeding ecology of fishes in a Brazilian reservoir: Lake Monte Alegre. Interciência, 18(06): 302-313.

BARLOW, G. W., 1972, The attitude of fish eye-lines in relation to body shape and to stripes and bars. Copeia, 1: 4-12.

BEDARF, A. T., McKAYE, K. R., VAN DEN BERGHE, E. P., PEREZ, L. J. L. \& SECOR, D. H., 2001, Initial six-year expansion of an introduced piscivorous fish in a tropical Central American lake. Biological Invasions, 3: 391-404.
BRAGA, F. M. S. \& BRAGA, M. A. A. S., 1987, Estudo do hábito alimentar de Prionotus punctatus (Bloch, 1797) (Teleostei, Triglidae), na região da ilha Anchieta, estado de São Paulo, Brasil. Revta. Brasil. Biol., 47(1): 31-36.

BRAGA, F. M. S. \& GOMIERO, L. M., 1997, Análise da pesca experimental realizada no reservatório de Volta Grande, rio Grande (MG/SP). Bol. Inst. Pesca., 24: 131-138.

CHEVALIER, J. R., 1973, Cannibalism as a factor in first year survival of Walleye in Oneida Lake. Trans. Amer. Fish Soc., 2(04): 739-744.

DURÃES, R., SANTOS, G. B. \& FORMAGIO, P. S., 2000, Observações sobre a alimentação do tucunaré Cichla monoculus (Pisces, Cichlidae) em um reservatório do Sudeste brasileiro. Revta. Ictiol., 8(1): 53-56.

FITZGERALD, G. J., 1992, Filial cannibalism in fishes: why do parents eat their offspring? TREE, 7(1): 7-10.

FOX, L. R., 1975, Factors influencing cannibalism, a mechanism of population limitation in the predator Notonecta hoffmanni. Ecology, 56: 933-941.

GIL, C. E. M., ANDRADE, J. V., MÉNDEZ, E. E. \& SALAZAR, J. M., 1996, Estudio preliminar sobre alimentación en cautiverio y contenido estomacal de Cichla temensis del embalse Guri, Estado Bolívar, Venezuela. Natura Caracas, 96: 42-47.

HALLIDAY, T., 1988, Sexual conflict and female choice in fishes. TREE, 3(6): 124-125.

HYSLOP, E. J., 1980, Stomach contents analysis: a review of methods and their application. J. Fish Biol., 17: 411-429. 
JEPSEN, D. B., WINEMILLER, K. O. \& TAPHORN, D. C., 1997, Temporal patterns of resource partitioning among Cichla species in a Venezuela blackwater river. J. Fish Biol., 51: 1085-1108.

LASSO, C. A. A., NOVOA, D. \& RAMOS, F., 1990, La ictiofauna del lago de Guri: composición, abundancia y potencial pesquero. Parte I: Consideraciones generales e inventario de la ictiofauna del lago de Guri con breve descripción de las especies de interes para la pesca deportiva y comercial. Memoria, 49(131): 141-158.

LOWE-McCONNELL, R. H., 1969, The cichlid fishes of Guiana, South America, with notes on their ecology and breeding behaviour. Zool. J. Limn. Soc., 48: 255-302.

MATALLANAS, J., 1980, Étude de Palimentation d'Ophidion barbatum (Pisces, Ophidiidae) dans la Mer Catalane. Cybium, 10: 81-89.

MATALLANAS, J., 1982a, Régimen alimentario de Ophidion rochei (Pisces, Ophidiidae) en el Mediterraneo español. Comparación con el de O. barbatum. Bol. Inst. Espa. Oceano., 6(315): 174-185.

MATALLANAS, J., 1982b, Estudio del régimen alimentario de Lampanyctus crocodillus (Risso, 1810) (Pisces, Myctophidae) en las costas catalanas (Mediterraneo Occidental). Tethys, 10(3): 254-260.

MATALLANAS, J., 1982c, Notes on the feeding habits of Epigonus denticulatus (Pisces, Apogonidae) in the Catalan sea (Western Mediterranean). Vie Milieu, 32(2): 77-81.

NOVOA, D. F. R., 1996, Aspectos generales sobre la biología, pesquería, manejo y cultivo del pavón ( $C$. orinocensis y C. temensis) en el lago de Guri y otras areas de la región Guayana. Natura Caracas, 96: 34-39.

NOVOA, D. F. R., KOONCE, J., LOCCI, A. \& RAMOS, F., 1990, La ictiofauna del lago de Guri: Composición, abundancia y potencial pesquero del lago de Guri y estrategias de ordenamiento pesquero. Memoria, 49(131): 159-197.
POLIS, G. A., 1981, The evolution and dynamics of intraspecific predation. Ann. Rev. Ecol. Syst., 12: 225-251.

SANTOS, G. B., MAIA-BARBOSA, P. M., VIEIRA, F. \& LÓPEZ, C. M., 1994, Fish and zooplancton community structure in reservoirs of southeastern Brazil: effects of the introduction of exotic predatory fish, pp. 115-132. In: Ecology and human impact on lakes and reservoirs in minas gerais with special reference to future development and management strategies. Ed. SEGRAC, Belo Horizonte (MG).

SANTOS, L. N., GONZALEZ, A. F. \& ARAUJO, F. G., 2001, Dieta do tucunaré amarelo Cichla monoculus (Bloch \& Schneider) (Osteichthyes, Cichlidae), no reservatório de Lajes, Rio de Janeiro, Brasil. Revta. Bras. Zool., 18(Supl. 1): 191-204.

THIBAULT, R. E., 1974, Genetics of cannibalism in a viviparous fish and its relationship to population density. Nature, 251: 138-140.

VANZOLINI, P. E., 1993, Métodos estatísticos elementares em sistemática zoológica. Ed. Hucitec, 130p.

WILLIAMS, J. D., WINEMILLER, K. O., TAPHORN, D. C. \& BALBAS, L., 1998, Ecology and status of piscivores in Guri, an oligotrophic tropical reservoir. North Amer. J. Fish. Manag., 18: 274-285.

WINEMILLER, K. O., 1990, Caudal eyespots as deterrents against fin predation in the neotropical cichlid Astronotus ocellatus. Copeia, 3: 665-673.

WINEMILLER, K. O., 2001, Ecology of peacock cichlids (Cichla spp.) in Venezuela. J. Aquaric. Aquat. Scien., 9: 93-112.

WOOTTON, R. J., 1990, Ecology of teleost fishes. Ed. Chapman \& Hall, London, 404p.

ZARET, T. M., 1977, Inhibition of cannibalism in Cichla ocellaris and hypothesis of predator mimicry among South American fishes. Evolution, 31: 421-437. 